\title{
Binge eating under a complex reading: Subsidies for the praxis of food and nutrition education
}

\author{
Compulsão alimentar sob um olhar complexo: \\ subsídios para a práxis da educação \\ alimentar e nutricional
}

Maria Lúcia Magalhães BOSI ${ }^{1}$

Márcia Junqueira TEIXEIRA ${ }^{1}$

Binge eating disorder is characterized by the consumption of large amounts of food in a short time, accompanied by the feeling of lack of control, remorse and guilt. binge eating disorder has a close interface with the obesity problem, a matter of great dimensions for health services, especially for the high comorbidity. Although this disorder is closely linked to obesity, a matter of great dimensions for healthcare, especially due to it high comorbidity, this disorder is still poorly known in its symbolic dimension, compromising actions directed to this dimension, among them those included in the scope of food and nutrition education. The purpose of this article is to delimitate the issue of binge eating disorder, under a lens based on complex thinking, in order to discuss and support the scope of the nutritional eating education, illustrating, with life experiences, the multidimensionality inherent to eating disorders. The analysis aims to highlight the challenge of working in educational practices focused on these complex disorders. Therefore, we articulated the theoretical with the empirical levels, revisiting, through a reflexive exercise, the discursive material obtained in a broad research carried out by the authors, guided by phenomenological-hermeneutics approach focusing on the understanding of binge eating disorder, with obese women who have also received this diagnosis. The analysis highlights binge eating disorder as an intense experience of suffering, which compromises the ability to innovate and reinvent behavior, in which food operates as an emotional cushion. In this context, healing requires taking an active and engaged place, feeling an active part in the self-transformation process. Thus, food and nutritional education should be conceived in the scope of a comprehensive care, as a fundamental and strategic space due to the specific nature of the practice, in potential terms.

Keywords: Bingeeating disorder. Nutrition. Obesity. Public health. Qualitative research.

\footnotetext{
${ }^{1}$ Universidade Federal do Ceará, Faculdade de Medicina, Laboratório de Avaliação e Pesquisa Qualitativa em Saúde. R. Professor Costa Mendes, 1608, $5^{\circ}$ andar, Bloco Didático, Rodolfo Teófilo, 60416-200, Fortaleza, CE, Brasil. Correspondência para/Correspondence to: MLM BOSI. E-mail: <malubosi@ufc.br>.
} 


\section{R E S U M O}

O transtorno da compulsão alimentar periódica é caracterizado pela ingestão de grandes quantidades de alimentos em um curto intervalo de tempo acompanhada pela sensação de falta de controle, remorso e culpa. Apesar de esse transtorno ter uma estreita interface com o problema da obesidade, reconhecidamente uma questão de grandes dimensões para os serviços de saúde, sobretudo pela elevada comorbidade, o transtorno da compulsão alimentar periódica ainda é insuficientemente conhecido em sua dimensão simbólica, comprometendo ações nesse sentido. Dentre elas, estão as que se inscrevem no âmbito da práxis em educação alimentar nutricional. O objetivo deste artigo é demarcar a problemática do transtorno da compulsão alimentar periódica sob uma lente fundamentada no pensar complexo, visando problematizar e subsidiar o âmbito da educação alimentar nutricional, ilustrando, com experiências de vida, a multidimensionalidade inerente a um quadro do espectro dos transtornos do comportamento alimentar. A análise visa evidenciar o desafio de atuar em práticas educativas voltadas a esses quadros complexos. Para tanto, articulou-se o plano teórico e o empírico, revisitando, mediante um exercício reflexivo, o material discursivo obtido em uma ampla pesquisa levada a cabo pelas autoras, orientada pela vertente fenomenológico-hermenêutica. Essa pesquisa buscou compreender o transtorno da compulsão alimentar periódica em mulheres obesas mórbidas diagnosticadas com esse quadro. A análise evidencia o transtorno da compulsão alimentar periódica como experiência de intenso sofrimento, que compromete a capacidade de inovar e reinventar comportamentos e na qual a comida opera como amortecedor emocional. Nesse contexto, a cura exige assumir um lugar ativo e engajado, sentindo-se parte integrante e agente de seus processos de autotransformação. Desse modo, a educação alimentar nutricional concebida no escopo de um modo de cuidar ético-político é um espaço de fundamental importância pelo caráter estratégico e especifico da sua práxis, em termos potenciais.

Palavras-chave: Transtorno da compulsão alimentar. Nutrição. Obesidade. Saúde coletiva. Pesquisa qualitativa.

\section{INTRODUCTION}

The purpose of this article is to demarcate the problem of Binge Eating Disorder (BED), under a lens based on complex thinking, in order to discuss and support the scope of Food and Nutrition Education (FNE), illustrating with an example, the multidimensionality inherent to a type of eating disorders. The analysis aims to highlight the challenge of working in educational practices focused on these complex phenomenon. Therefore, we articulated the theoretical with the empirical fields, taking the discursive material obtained in a comprehensive study aimed to understand a particular eating behavior - BED, with morbidly obese women who also have this diagnosis.

From the perspective adopted here, understanding the phenomenon is what enables us to recognize it in its multidimensionality ${ }^{1-3}$. There is no effective education if there is no clarity about the nature of the phenomena on which such practice focuses. Evoking the complexity implies a break with the biomedical model, still hegemonic in the field of food and nutrition ${ }^{4}$, that is, incorporate it dialectically, which differs from denying it. We start from the premise "that in the constitution of behavior and eating behaviour in particular, complex processes that interact dialectically were outlined" 5 , and the biomedical model is insufficient to encompass the complexity of the theme ${ }^{4}$. Recovering the complexity of phenomena, as we intend to exercise in this article, is therefore, step of the educational process in food and nutrition field.

Alluding to the complexity, we take as inspiration Morin's ${ }^{6}$ propositions, for whom the term complex announces a weaving that integrates and reconnects.

... There is complexity, in fact, when the components that make up a whole (such as the economic, political, sociological, psychological, emotional, mythological aspects) are inseparable and there is an interdependent fabric, interactive and inter-retroactive between the parts and the whole, the whole and the parts (p.14).

The complex thinking invites us to overcome the traditional educational-taming 7,8 
dimension to penetrate the in-depth understanding of the genesis of the phenomena and, above all, to rescue the subject disappeared in the biomedical model; a model which allows the duality food-nutrition, for its disjunctive and reducing character. Model that reproduces in educational practices in health, the education marks received from the broader educational system:

"In elementary school, we are taught to isolate objects ... to separate disciplines (instead of recognizing their correlations), to dissociate problems rather than gather and integrate them. Forcing us to reduce the complex to the simple, that is, to separate what is connected; to decompose and not recompose; and eliminate all that causes disorders or contradictions in our understanding"6 (p.15).

How often do we see that separation in the analysis of the problems in the health sector and therefore in educational activities addressed to them? Thus, despite the use of this dichotomized expression (food - nutrition) in this article, we do so with reservations; especially with regard to what is conceived as nutrition education, object which goes beyond the limits of this analysis, but which had already approached other discussions that took as object the food and nutrition area and critical categories revolving around it ${ }^{9,10}$.

Aware of the challenge of this exercise regarding the extension limits, we have adopted a path in which we outline, briefly, the BED phenomenon. Next, we approach the empirical material, taken as an illustration of the complexity we intend to evidence, moving from the nosological focus to reconfigure it as a complex experience, placing it in the social historical context in which it is produced and gradually increases, in terms of magnitude. In order to do so, we have developed a reflexive exercise, retaking the material present in statements obtained in an empirical ${ }^{11}$ research of women who experienced, in their lives and bodies, this disorder.
From this material, we seek to extract subsidies, in the voices of the women participating, intending to guide the nutritional eating education, learn from these women what they should be offered, in order to build an effective practice in this sphere.

\section{Binge eating disorder: some contours of the phenomenon}

Obesity can be defined as the excessive accumulation of adipose tissue in the body. The pathogenesis, as known, is multidimensional, although this multidimensionality is often overlooked in the design of interventions. Among these dimensions, there are genetic, metabolic, neuroendocrine, socio-cultural, family, psychological aspects $^{12-14}$. Far from understanding them as 'factors' in a fractional perspective, as the descriptive epidemiological lens operates, such aspects interact to form an amalgam that signals the alluded complexity.

The prevalence of obesity has increased markedly in recent years worldwide, bringing the disease to a global epidemic condition, becoming, at present, one of the most serious public health problems. Population-based studies in Latin America, for decades, have shown a worrying situation:

It is the phenomenon of nutritional transition that overloads our health care system with a growing demand for care for chronic diseases related to obesity, such as type 2 diabetes, coronary heart disease, hypertension and various cancers ${ }^{14}$ (p. 21).

Obesity is only considered an eating disorder when associated with binge eating disorder (BED), defined in the literature as follows:

"The eating behavior characterized by eating large amounts of food in a limited period of time (two hours), accompanied by the feeling of loss of control over what or how much you eat, is known in English as binge eating - in Portuguese, Compulsão 
Alimentar Periódica (CAP). When these episodes occur at least two days a week in the past six months, associated with some loss of control characteristics and are not accompanied by compensatory behaviors directed towards weight loss, make up a now called syndrome of binge eating disorder - in Portuguese, Transtorno da Compulsão Alimentar Periódica - TCAP (DSM IV) ${ }^{15}$ (p.215).

Several studies have shown that:

There is a subpopulation of obese patients with similar characteristics, who do not respond to behavioral treatment for weight loss and have high rates of mood disorders and anxiety disorders. These obese people present eating compulsion and BED and, even with a high degree of suffering and loss in life, they generally do not receive specific and appropriate treatment ${ }^{13}$ (p.2).

Binge eating disorder is a new diagnostic category, only recently, in 1995, included in Appendix B of Diagnostic and Statistical Manual of Mental Disorders IV (DSM IV) ${ }^{16}$ Text Revision. This category demands new studies and research, since patients have high rates of anxiety and mood disorders, problems related to body image and sexuality, not responding to traditional treatments for weight loss, requiring an appropriate and specific care for their problem ${ }^{17-19}$. It is known that obese people are already suffering from health problems, but the risks increase significantly if they also have BED ${ }^{20-22}$. At the end of her study, Borges $^{22}$ concludes that "Future studies must be directed to verify the etiology of BED, as well as the risk factors for binge eating. This will favor the adoption of preventive methods and specific treatment".

Most studies indicate a prevalence ranging from $16 \%$ to $51 \%$ in samples from patients seeking weight loss programs who are compulsive eaters ${ }^{23}$. This shows us how this problem requires better understanding by health professionals, notably by nutritionists, given their proximity to the management of these conditions, so they can draw more and more specific actions for this segment.

In short, according to the aforementioned data, BED has been a major problem both in individualized clinical treatment as in the field of public health and when associated with obesity, the treatment becomes more complex, requiring a differentiated care for this population ${ }^{18}$. But what does it mean? What consequences does this have on educational practices in eating and nutrition area? What are the challenges to this practice?

Undoubtedly, clinical studies as well as statistical and epidemiological studies herein bring important elements for the definition and description of BED. However, to understand the situation of being a woman who is obese and compulsive eater, and design interventions, mainly education ones, it is necessary, according to the alluded complexity, to amplify the dialogue and resort to other theoretical and methodological resources.

Knowledge is the cost of many attempts and the incidence of many light beams by multiplying the different points of view. The incidence of a single beam of light is not enough to illuminate an object. The result of this experience can only be incomplete and imperfect ... . The use of other light sources may form an entirely different object, or display entirely new dimensions ... ${ }^{24}$ (p. 27).

In this sense, research conducted by qualitative approach have much to light, exploring the disease in the voices of those who suffer from it, in order to clarify what "upsets the body and deregulates eating" 25 . Thus, as already anticipated, we will visit a research with obese women with BED, previously screened by psychiatrists of specialized services in compliance with binge eating and obesity in a public hospital. In the case of this essay, the information was not generated in the empirical research mode, but, as previously alluded to, resorts to results of 
original study entitled: Hunger for life: experiences and perceptions of obese women with binge eating disorder ${ }^{11}$ are resumed. The method I adopted corresponds to the reflective-analytical one by which we approach the discoursive material of that research, in order to illustrate the problematic presented here. However, it seems appropriate to present, briefly, the foundations and the setting of this research, upon which this analysis is based.

The study, conducted in the city of Rio de Janeiro, was guided by qualitative tradition within a phenomenological-hermeneutic-dialetic ${ }^{2}$ perspective, having the objective to understand perceptions and experiences of morbidly obese women suffering from BED. In this research tradition, we have found many reasons to rethink the practice of FNE. Thus, we are going to signal along the explanation that follows, concerning the methodological foundation, some developments which also apply to the scope of this analysis - the practice of FNE.

Forghieri ${ }^{3}$ points out that the hermeneutic phenomenology advocates a polysemic and symbolic dialectic, comprising various interpretations and enriching with the conflict. This is a position of ideological and political engagement, as it ends up having an eminently practical significance in relation to history and society. This is about 'listening' to people, especially when they have no voice in a process so that their otherness questions my identity. This is difficult in all senses. But it is also the most important because only the others, as such, can provide openness and access "to sense, to the senses and to more sense" 3 (p.47).

In this specific branch of qualitative research, the reseacher starts from a basic assumption of "understanding" the phenomenon, understanding that in comprehension, the object of the study necessarily implies the presence of the subject that will influence not only how to read the object but also its own existence. According to Morin", "the subject appears in the reflection on himself and according to an inter- subjective knowledge mode, subject to subject, which we call comprehension" (p. 118).

Another important and already mentioned aspect refers to understanding, in a comprehensive, complex perspective, that the object is contextualized, inseparable from his world and that is immersed in a peculiar dynamism, leading to constant change. Thus the truths are not absolute, and knowledge is always relative.

Within these epistemological premises resides a first step to be operationalized in FNE, namely the teachers' necessary reflexivity, listening to themselves, their own experiences, their preconceptions, in the relationship with the student. The opposite of that defines what we call here the traditional taming education.

For Amatuzzi², phenomenological hermeneutics research "is an elucidation of living, but which starts from Heidegger's assumption that interpretation is essential in comprehension" (p.6).

Bruns $^{26}$ stresses the researcher's inability, in qualitative approach, to separate and divide the human fact as it can be done with other facts. In addition, he points to a dialectic integration between researchers and subject that causes, contrary to what happens in the objective relationship of positivist science, the researcher and the subject to be interwoven and interacting; ie the researcher's relationship will be subjectsubject as the two poles "produce meanings". How often is this aspect overlooked in FNE, especially when guided by the pedagogy of transmission? Such perspective, of course, dissociates emission from reception, concentrating power in the transmitter pole and restricting interactivity ${ }^{7}$ and autonomy ${ }^{8}$.

According to the previous explanation, 15 obese women were interviewed in the aforementioned research. They had been screened by psychiatrists of a specialized service related to Obesity and Compulsion Eating in a Public Hospital in Rio de Janeiro and diagnosed according to the criteria for BED under CID $10^{27}$ and DSM-IV28. 
These patients were, at the time of the study, between 18 and 55 years old, since these conditions begin in the adolescent's entry into adulthood and can be perpetuated throughout life 22,29 .

From the discursive material submitted to hermeneutic analysis emerged the network of meanings, in which only one of the themes (the genesis of BED) is here taken as inspiration to problematize the practice of FNE, "listening" to the women and building a narrative in which our eyes intermingle.

\section{Listening to experiences and learning from the women}

The central theme of the network of meanings of the research whose empirical material illustrates this exercise is called "Genesis of BED" and is composed by four macro dimensions: 1) Unique routes, understood as a set of individual aspects that encompass both behavior and biological aspects; 2) Family dynamics, encompassing a wide range of family experiences, especially the mother-daughter relationship; 3) Social surroundings, concerning events that characterize the social life, the objective and subjective plans, involving the construction of ideals of beauty, stigma and prejudice against the obese, among other triggering elements of BED and obesity and, finally, 4) Therapeutic itinerary, in which central elements are evident to inspire more personal, wholesome and humanized care lines. As already clarified, differently from presenting the results of the qualitative study, the purpose of the exercise here developed is to 'listen' to what the women tell us, deriving subsidies to the scope of FNE actions in different plans.

We have seen, through the deponents' accounts, a difficulty presented by these women to digest suffering, coupled with a generalized hypersensitivity, as we can see below:

I know I get fat because I did not learn to digest my problems, I have to learn to live with them because we all have problems. But I need to learn to manage them properly... I think I cannot be so sensitive, it is as if I were a baby, but I've grown up (Beatriz).

Oh, it's hard to swallow. Look, it's worse than my husband's rum. My daughter came out of me, I faced everything, raised her, wanted her to graduate, she turned to me on my birthday and said 'happy birthday mom, and I'm working in a massage parlor'. There is no worse present for a mother who always had a life, I was always honest, correct, pretty, I never prostituted myself, never got involved with criminals. So these things just make me want to eat, I do not drink, I eat... I swallow the food, make myself meals and eat nonstop ... (Lita).

Cukier ${ }^{30}$ coins the term emotional skin to explain the ability the individual has to endure frustrations. According to the author, this emotional skin should be expanded, through the therapeutic bonding, in the case of people who have suffered abuse and neglect in childhood. This bonding should help them contain and organize their emotions. In the case of our deponents, this involves creating new possibilities of casing other than food.

Regarding $\mathrm{FNE}$, it is revealed in these passages the importance to consider the dimension of the bonding, in the broad conception of this concept $^{31}$ as well as deepening of educational aspects which operate to "educate sensitivities", using art as a resource and articulating interdisciplinary projects congruent with the nature of the problem.

The lack of personal project was another aspect that has emerged as an important triggering factor for compulsion crisis:

Oh, l'll eat... I'm fat anyway, l'm horrible! What am I living for? I reached the point of thinking that I no longer needed to live. I raised the children and they are grown, 
living their lives... I have a husband, he is very good, but doesn't give me any support (Mel).

In this talk we see how this deponent's life is devoid of a proper sense which goes beyond her role as a mother and wife. A few decades ago, motherhood and domestic activities could fill the female existence, which does not happen anymore today for the younger generations. This is because the norm of work is strongly internalized by women and the fact that work builds more strongly the social identity than before. In the study, the author reports that when doing the interview validation with this deponent and giving her the transcribed interview, an interesting reaction was processed. When reading on the paper the transcript of the conversation, she was extremely shocked by the sentence that appears above ("I reached the point of thinking that I no longer needed to live"...) and commented:

Wow, I don't remember telling you that. I never talked about these things so openly with anyone, I didn't know I was feeling so bad. I said I didn't want to live anymore. It's very different to see all these things that I told you written on paper: it made me stop and think. Now l'm willing to invest more in my treatment. I was even thinking about quitting ... it seemed that it wasn't adding anything, but l'm willing to take care of myself, it was very important to me that conversation we had (Mel).

The author declares "surprise" with the effect caused on that deponent because she has been able to not only tell her story during the interview, but mainly to re-read it. Now she seems to have, finally, appropriated her speech. Metaphorically, we can compare the use of the speech to the compulsive way she uses the food, ie, speaking quickly, aiming only to vent, without getting in touch with what is being verbalized. Not tasting the words, the same way she does not taste the food at the time of the binge.
Bringing this experience from the research sphere to FNE practice, we believe that the assistance to these people could incorporate this information the deponent accidentally provided, offering opportunities for these people to get in deeper contact with their own speeches. More specifically, the use of narratives based on case histories and the creation of spaces for dialogue in which subjectivity is recovered in the educational process are techniques apparently effective for a realization, in the direction of new choices, concerning behaviors.

\section{Family dynamics}

Another important dimension of the network of meanings of the empirical study concerns the family dynamics. In this regard, we can rely on Marcus cited in Fairburn \& Wilson ${ }^{32}$ whose research with a group of 336 adults seeking treatment for obesity, which identified 164 obese patients with BED. When comparing them to the obese without BED, it was found that the former had significantly higher rates of first-degree relatives with alcoholism, as well as histories of having suffered physical and sexual abuse in childhood. This research seems to confirm the harsh reality of some of our interviewees, as we can see in the following lines:

We have lived it since we were children, only we did not know he (father) had schizophrenia. He was always like that, beating us. He was always very aggressive and I always lived in all this tension. Now I'm calmer because l'm not there anymore (Mona).

You said he pointed a gun at you (Interviewer)?

He also put the gun on the head of my mother and said, 'You will be on Linha Direta (a TV show about crimes), because I will kill you'. "So I told him 'then you kill her after dinner because now l'm starving (Mona). 
I have a hard time remembering my childhood, but what I remember is all bad (Vencedora).

In these three excerpts from interviews, the study participants make clear the correlation they make between BED and complicated family dynamics they were submitted to. Cukier ${ }^{30}$ shows that children who did not have their basic security needs and dependence satisfied suffer serious damage in their basic identity. These children begin to doubt whether they are good, worthy of affection and recognition, coming to judge their wants and needs as illegitimate. At the same time, as they need to keep the idealization of the parent on which they depend to survive, they try to take the blame for adult abuse, starting to believe that they are to blame for the bad situation they are in, believing they have a serious defect. Such children also develop a disbelief in trusting other human beings, since they could not trust their own parents. Because of this, we can wonder if the food could symbolize, as pointed out by Cukier, a substitutive relationship in the lives of these children, reliable and protector, for it, the food, does not leave them at the mercy of another human being. In the company of food, it is the very child who is control, just depending on her own to meet her needs.

Making a connection with the biological level, we can think of antidepressant power of some foods, for example, chocolate and sweets. These foods momentarily increase serotonin in the body and also have a sedative effect. On this issue, Greeson $^{33}$ stresses that meals with excess carbohydrates and sugar favor the release of serotonin in the body; which is a neurotransmitter that causes the human sense of happiness and well-being. Thus, there are people who 'discover' that by ingesting sugar and carbohydrates they can increase the levels of dopamine in the body and provide themselves a relief for depressed mood. These findings help explain why the favorite food at the time of compulsion is just food high in sugar and carbohydrates.
In the preceding paragraphs, are important parts that help us solve the riddle of this behavior, pointing to intense suffering linked: to the blame for 'personal failure'; to doubt regarding the affection and recognition they deserve; the legitimacy of wants and needs, offset in comfort food, often considered in FNE actions as mere vehicles of nutrients, directed to biological bodies, and our task as nutrition professionals to seek their suppression, by means of information. What these women seem to tell us is that we need to be very careful when you want to 'teach' to eat or deconstruct behaviors that support them. This is not about choice or knowing what the best choices are. That, many of them know, as they learned it in the painful therapeutic itinerary that took them to chronicity. It is about building another 'feature' in the relationship with the food-world, for which the educator is the central figure if in the educational relationship, connection and shelter are built according to a practice in FNE founded in humanization and comprehensiveness of care, as prescribes an attention model based on an expanded concept of health, and by extension, food and nutrition.

Looking at the statements extracted from the refered research, it becomes easier to understand how the compulsion cycle starts and how necessary it is a paradigm that incorporates the subject of practices. Cycle that emerges due to a combination of biology and culture, chemical aspects associated with dimensions related to the personality and development. Chemical factors are triggered by nutritional properties, such as the carbohydrate and sugar described above, but get in synergy with existential issues, such as failure to receive care and protection during childhood, so well described by Cukier, low self-esteem and helplessness, propensity for depressive disorders, changes in circadian rhythm, triggering binge $\mathrm{e}^{20,30}$. This illustrates in an emblematic way the multidimensionality and complexity of the phenomenon here focused.

In the case of our deponentes, these predisposing aspects are intertwined in such a way 
in the manner of a mosaic, there are times when it is difficult to systematize all the nuances of this complex issue. For example, in the following report, the sexual abuse suffered by the deponent cannot be understood in isolation; it is one more element to add so that the compulsion and obesity are kept in her life not as another disease, as assumed by reductive biomedical view, but also as a symptom protector of Mona's (nickname of our interviewee) mental and physical integrity. In her case, morbid obesity also protects her because it makes her literally a big, strong woman, and the compulsion possibly prevents her from contacting memories and unbearable feelings, emotionally.

I was eighteen years old, it was very hard to deal with because it was a handsome guy, I did not understand the reason for a cute guy to do that. I only came to understand later, because I knew he was using drugs. It is very difficult for me to talk about it. It was as if I was wrong, as if I had given opportunity for that to happen ... I was talking to my mother but she would not listen ... then l've been scared and that's why I don't like to go out alone (Mona).

In this talk we found that it affected her trust in people and in herself, since she questions if she herself did not make the situation easier and to prevent further sexual abuse, she limits her freedom and autonomy, not going out alone. This results in a probable increase in her obesity and BED, as social isolation is one of the factors that favors the compulsion attacks, as well as the maintenance of the condition. Such aspects escape an 'objective' view, the biomedical model claim that underlies so many guidelines and food guides. Restricting nutrients and reshaping bodies seeking an abstract health, idealized, unrealistic for FNE recipients, is a misconception that demands a reconfiguration of health, eating and, especially body concepts, giving back the marks of existence and its historical character.

Some have said that the body does not lie. More than that, it tells many stories and, in each, there is a sense to find out. As the meaning of events, diseases or pleasure that animates some of its parts. The body is our most archaic memory. In it, nothing is forgotten. Each event lived, particularly in early childhood and well into adulthood, leaves on the body a deep impression ${ }^{34}$

Also, in relation to the family dynamics aspect, another sub-theme that emerged was the family overprotection which can be exemplified by the following quote:

He (father) doesn't want me to work. He says 'Oh, I don't want her to work because, poor thing, she's fat, heavy, it's exhausting for her to take a bus, get off, go to work. 'He makes sure I don't work. I tell him, 'Dad, I'm fat but I'm useful!' And he says' of course you are, but this story of working is another matter (Mona).

In this talk we can see a complex family dynamics in which, for the family, it is more interesting that Mona works within the family circle and does not take risks to create her own experiences in the outside world. Important to note that this is the same deponent who had the duty to protect the mother of her father's fury episodes due to schizophrenia. She has a very important and specific role in this family, which is to be the one that absorbs crises and family difficulties. There seems to be no coincidence that she must be a "heavyweight". This is also the same deponent who was sexually abused, feeling frightened of men and the outside world. It is evident, therefore, the synergism between distinct plans that, interlaced, help our interviewee to remain in morbid obesity and BED.

Nunes et al. ${ }^{13}$ indicates that regulator place of family homeostasis, remaining stuck in the parental conflict, as in Mona's case, whose morbid obesity makes her remain linked to her family dynamics and the role of "firefighter" for the family's emotional fires, as we see in her report below: "It was horrible, sometimes I wanted to leave and could not because he was fighting with 
my mother. I was afraid of him doing something with her, if she stayed alone with him, so I stayed at home (Mona).

Another important family trait revealed in the statements of the interviewees was what we called family wealth that is summarized in the following quote:

Then I started to observe my family's behavior. I learned to watch my family and found that everything revolves around food. So I started to see this thing, the food reserve, you have a lot at home, my mother raised us like that and my sister is raising my nephews the same way. For example, my family is like this: we discovered a popsicle factory, then any normal person would go there and buy some flavors or some units only, but my family bought 150 popsicles. Why? So as not to have to go back there... it is the famous reserve (Geórgia).

Geórgia portrays the need that her family has to always have large amounts of food at home. The family priority is to have a food reserve and shows us how this feature, when not observed and understood, is passing from generation to generation.

In the case of our respondents, the mother's self-esteem and the relationship she has with her body, sexuality and food seem to directly affect her daughter's self-esteem, as we can see in the following report:

It took time, filled my life with a problem that was not mine. As it fills up today drives me crazy today, torments me today. Today I'm looking for a house to rent because I can not stand living near her (mother), so this is conflicting to me ... Not that I expected to win, but at least I wanted peace and quiet. I have no peace, I have no quiet time, I am her daughter and what do we expect from a mother? Love. And it's all that my sister and I didn't have from an early age (Beatriz).
My father's family is all obese. My mother's family is not, but my mother was very controlling, is always on the soup diet, is always keeping slim, has always been on a diet ever since I can remember (Babi).

She comes to my daughter who is only fourteen and says: 'Do you want to eat a candy that grandma saved for you?'; 'I do'; 'But your mother will not eat it, Jesus, she's huge! With all this fat, I've never seen it... you say are on a diet, is on treatment... does everything and is still so horrible... . When I was a kid, my neighbor told my mother to dress me in a corset so I would not be horrible and my mother answered, 'No, Verinha's very cute, a chubby child'. And when I was a kid I ate too much (Vera).

In these lines we can see mothers-daughters relations permeated with ambivalent feelings of love and hate and filled with double messages. In the last line we can see these messages being passed to the 14-year-old granddaughter who has to listen to her grandmother disqualifying her mother, in a humiliating situation of verbal abuse and at the same time, getting a candy from her grandmother. The contradiction is that when the daughter was a child, her obesity was appreciated by the same mother who now criticizes it. The discussions in this context emphasize the importance of understanding the obese person's family history; they deal with their bodies and with the food. It is noteworthy, therefore, the importance of considering the family dynamics, exploring this context, including the family in the FNE actions, an aspect that seems obvious, but is often subtracted in practices that focus on the individual, out of context of life, distant from the people with whom she lives and, as we have seen, play a key role in the genesis, reversal or chronicity of these behaviors.

\section{The social environment}

Another aspect mentioned was the social environment that operates in synergy with the 
aspects already listed as a triggering factor for BED and obesity, highlighting the financial difficulties speeches, violence, "stress level" and the strong stigma they carry:

Today the level of stress is very large and stress helps a person to eat. Unfortunately the only distraction for the common people is what? Chew (Vera).

"The financial situation is very important, it worries me more than anything else, although I am aware how to deal with it, thank God. Maybe if I had not taken this drug I would be crazy (Clara).

"This compulsion thing, I wanted to calm it down, I wish I could resist eating even when I know I didn't pay the bill. When I can, l'll pay ... I wanted to lead a better life, that is not life (Lita).

Through these testimonies, we can see how stress, resulting from different levels, including urban life and financial problems, affects the interviewees' eating habits. People subjected to prolonged stress may have their physiological perceptions of hunger changed. In stressful situations, the hunger physiological center is unbalanced and electrical impulses are sent to it out of time and purpose, even after completing a meal ${ }^{35}$.

We consider that in the case of Rio de Janeiro - scenario of the research that illustrates our exercise, whose levels of violence reached alarming levels, restricting life in the public space, moving around, together with the issue of unemployment and impoverishment of less favored classes are aspects that lead people to live with high levels of stress, a daily reality. To these factors, against which disadvantaged segments are the most vulnerable, we add those specific to the group in question: the stigma against obese and social isolation undergoing due to the fear of being humiliated in public areas and public transport, the fact of not fitting in the chairs and other constraints. For these people there would still be the beach, important leisure space in the carioca culture as a way to fight stress. Although available and free, for the obese, that leisure is presented loaded with censoring looks from the so-called normal and fit population. Thus, the cheapest and safest recreation is actually staying at home eating more affordable products, rich in carbohydrates and lipids and watching television, that is, gaining more weight. Behavior often condemned almost in a "moralizing" manner by professionals, often due to ignorance or disregard that this is not done by choice.

As for the prejudice and stigma in relation to obesity and the social construction of ideals of beauty that start dictating behavior - both towards restriction and compulsion, this by offsetting dissatisfaction with body image, many are the aspects to consider and literature has deepened analysis, in interface with the media and consumer society nowadays ${ }^{36}$. Failing to deepen this theme to the necessary extent, we illustrate the findings of Stenzel, coming from a qualitative study with 25 adolescents between 11 and 21 years old in Porto Alegre ${ }^{37}$. In this research, which aimed to investigate how adolescents perceived and experienced their bodies, the author found that the fear of getting fat, the prejudice against obese people and individualism are features present in all focus groups conducted:

Social representations of obesity and thinness are based on prevailing social values, such as individualism. The stimulus to weight control and dietary restriction is indirectly a reinforcement to the individualism, narcissism and consumerism that prevails in our society. We are encouraged to achieve individual bodily perfection (in this case, the thin body) instead of longing for a better, more caring, more egalitarian society. In the adolescent universe, individual goals overlap the collective ones; most teens are facing their own happiness, and values such as solidarity and cooperation are not compatible with competitive values and individual success that appear in these participants' speech ${ }^{37}$ (p.118). 
Another important issue that the author pointed out in her analysis was the cult to thinness as an ideological issue of social oppression related to gender. The teenagers interviewed seem to have introjected thinness as a social mobility passport stimulated by culture, requiring them to match others' desires rather than discovering their own goals and needs. She concludes defending focus groups in which teens can create a space of resistance and criticism where all these issues can be strengthened. It is urgent action within FNE, given the high vulnerability of the adolescent group to eating disorders, either in restrictive mode, the anorexia case or in disorders related to episodes of binge eating, as bulimia and BED.

This proposal is in line with findings related to the importance of FNE work with groups to be translated for obese women with BED, not only as a therapeutic space, but also as a political space, in that they may question the ideology that subtly and insidiously, ends up privileging the richest strata, as if thin women were (morally) superior. This is a type of ideology that, though lined in society, is unfair because it favors the wealthier classes, considering that building the perfect body is an extremely absorbent and costly endeavor. In addition to groups, social networks and other resources such as entertainment education, in which characters of prime-time TV programs such as soap operas and series can counter-problematize behaviors, to the same extent that they build them, and should be appropriated in FNE actions.

\section{Experiences in therapeutic Itinerary}

In the case of a focus on FNE, a central dimension of the network of meanings arising from this research concerns the experiences lived in the painful and extensive therapeutic itinerary, searching for relief and care. This theme houses many dimensions, from which we have extracted the following: the pilgrimage; the difficulties in adhering to treatment; and the healing process, for bringing many elements to be considered for a praxis in FNE that breaks with the limits of the biomedicine look.

Andrade ${ }^{38}$ uses the term pilgrimage, which we also chose to adopt here, to report the fact that the deponents of her research have seen several experts, and, by not feeling really heard, left in search of new therapeutic ties through so many specialties without effectively adhering to treatments. This kind of behavior also appeared in the accounts of our research:

I don't even remember the types of medicine I took. There were formulas, I went to a doctor and you bought the formula in his own office and you didn't even know what it was and he didn't tell you what was inside [...] So it ended there, you went back to eat the same way (Bia).

I think when I did treatment elsewhere which was a formula, the doctor didn't have the attention to talk, to know what I had, what I was feeling ... (Mona).

Before I used formulas, I went to endocrinologists, those who psychograph because they usually don't look at you (laughs). They say it's personal but it's not, the formula is the same, and it was really getting me tired. Then I came to the conclusion that it's not diet, not medicine, it's nothing immediate that can be solved. It had to be a deeper treatment, I wanted to change, I had to think differently about food and had to act differently (Geórgia).

The deponents denounce here the lack of information and alienation from the treatment to which they were subjected. They did not feel treated as subjects of their own history, able to give an opinion about the treatment, being relegated to the role of consumers of unknown formulas without feeling heard, nor confirmed in their existential pain. Also, the dimension difficulties in adhering to treatment houses the aspect magic solution, in which apparently fast and easy formulas are wished, avoiding the need for a deeper engagement with the healing 
process. It is as if something external could exempt these deponents from dealing with the creation of an internal self support. Among the magical solutions mentioned is the surgery to reduce stomach:

I think, for the chubby, the best thing is the stomach surgery, I think that's the only thing that solves (the problem). Staple it already and just get on with it. It is the only way because the chubby will not be able to fill the stomach or else he'll feel sick, so he'll really need to stop eating... (Dani).

Every fat has this expectation, he wants to lose weight yesterday, he arrived today, but wants his weight loss for yesterday ... (Bia).

Actually, I don't accept it [treatment]. I don't accept it because I want to lose (the weight) soon, I want to see myself slim quickly so I can't accept [...]; for me, everything has to be fast, so as I can't solve this weight thing I get very nervous, really (Gordinha).

The first witness describes the surgery as an external brake for binge crises, as if the problem was located in an organ, the stomach. When clipped, it would prevent the obese person from eating too much, as if BED had a surgical solution. Her speech comes loaded with a punitive proposal to herself and other obese, as if it had absorbed from the culture the message that the obese person has no will power and is inferior to the thin, so she deserves a radical solution, surgery. This kind of thinking has also emerged in Stenzel's ${ }^{37}$ study, in which adolescents from Porto Alegre, south of Brazil, defined obese people as careless, that remain in this condition because they want to, since there are numerous treatments for weight loss and the media sells so well the idea that body self-transformation is accessible to everyone. The speech of one of our interviewees perfectly illustrates this type of reasoning is simplistic and cruel way at the same time, it reinforces the feeling of helplessness of the obese person:
People demand 'and then when are you going to lose weight? Why don't you go to Xuxa's Makeover (TV show)? She'll send you to a spa... And I thought to myself, I'll never do it', I found this kind of comment horrible (Geórgia).

The name of the makeover TV show (aired on a high audience program) speaks for itself, revealing the magical aspect of the proposal and making it seem deceptively easy a situation which, to our witness, is extremely painful and complex, as we have seen in this analysis. As for the controversy regarding the surgical solution, lipophobicity that marks contemporary societies ${ }^{39}$ and the fast pace helps clarify this movement toward quick and magical solutions. We witnessed a popularization of this surgery combined with a trivialization process of the risks it involves, causing increasing demand for this alternative as a solution, often disregarding its risks, although the literature documenting that obesity surgery it is a complex procedure, which may lead to complications or intercurrences ${ }^{40}$.

As professionals working in the FNE circle, we need to design public health campaigns and other actions to explain to the population the risk of certain 'magic diets' as eliciting eating disorders and as responsible for the chronicity of BED. As widely reported in the literature, the more restraint, the more binge eating episodes increase, leading the obese to fall into a vicious cycle that generates powerlessness and low self -esteem. At this point, we lack clear, objective and accessible information to all levels of the society, especially the poorest population, which leads them to become easy prey of such magical solutions. More than that, FNE actions, a food safety perspective must be directed to the control of information and advertising, as performed on issues such as smoking, breastmilk substitutes, among other successful experiences.

As for the attention received in the different areas they have recurred to in their long journey, the interviewees praised the treatment they were receiving at the time of the research, 
in a public institution, supported by an interdisciplinary team, in which FNE actions were included, with an interdisciplinary view. This satisfaction stemmed mainly from the fact that they felt heard and considered in their emotional needs:

I'm being very well treated. Today this interview is being a super cool thing, I'm being heard. This messes with us, encourages, stimulates you to want to participate, to want a nice result, not to want to fail. For example, here I have never missed an appointment; it's a new thing for me, because I was always a latecomer (Geórgia).

We, the obese, need it to not seek support on food when we leave here. We need that support, not only this support to get here and the doctor gives me medication ... (Beatriz).

I have the impression that I'm going to improve, I have faith and willpower. These lectures, this kind of treatment l've never had. Here, doctors want to talk, they have a very special care, I feel that here I have importance (Mel).

The deponents clearly talk about what motivated them in the treatment: the kind of empathic relationship they developed with the team and with the other women under treatment. It is the welcoming reception and the established relationship that allowed them to remain under treatment, as well as the confidence that they are being seen in a global manner by various professionals, including a nutritionist.

Hycner \& Jacob ${ }^{41}$ point out as a key factor in healing what they call confirm the other. Confirm means a conscious effort to look at the other as a unique being, singular, who is entitled to being diferente; respect and accept them in their ability to make choices and be responsible for them. It's that kind of attitude that seems to make a difference for these women, compared to previous treatments and it is this look that needs to be preserved in the practice of FNE. Guided by this premise, it is necessary to increasingly invest in inventiveness focused on building more evocative and sensitizing techniques, which combine interdisciplinarity ${ }^{42-44}$, encourage group support, the interaction of people suffering from the same illness, the inclusion of rituals such as meals preparation, meetings, forms of body expression, verbal, artistic, which mobilize the complex mosaic summarized in this article. Fellipe ${ }^{45}$ points out that:

There is growing evidence that social support is one of the best forecasts in relation to the lifestyle change. Many individuals with excessive weight find the motivation and the energy needed to keep their diet plans thanks to the support of their peers, provided [by] the support group [which] is one of the most powerful and therapeutic forms of help.

In relation to experience healing, considered out of chance in the biomedical model speech, we had a single speech by a deponent who managed, through interdisciplinary treatment, to reach the next level:

In compulsion you don't taste the food. You eat as if it was paper, to fill, but not now, I can taste the food. I prepare the food, prepare salad, make it all colorful to look good and have the pleasure of eating. I'm taking pleasure in eating again... . For me, this is quality of life, this is healing. And l'm going to get what? Life! It's not that I'm not going to eat, l'll eat, but not that way at that fast pace; I was eating two, three sandwiches, not anymore. Life is not only that and that is not pleasure, it's unpleasantness. There are much better things, much better flavors and you will have another quality of life (Beatriz).

This deponent, despite the weight loss, has not yet reached a body mass index that puts her out the obesity range, but already seems to have 
advanced in her BED healing process and is developing a different relationship with her body and the food. She says she gained life, flavor and pleasure, she says she is being able to make for herself colorful dishes and compares the compulsion to eating paper, something that always tastes the same, a repetitive gesture that does not really feed. For her, healing is to have managed to slow down and feel the taste of life.

For Canguilhem ${ }^{46}$, returning to normal is a social concept. Healing does not mean returning to how it was before becoming ill, but building a new internal order that involves the transformation into a less limited way to work. For the compulsive eater, this means that cure is a subjective concept. She will have to find a new way to express herself and be in the world rather than simply resolve the issue of weight loss and compulsion, since these people are suffering from what Canguilhem called "death of normativity" 46 . For this author, there are two types of unprecedented behaviors of life: those which are stabilized on new constants, which he calls normal constant propulsive value and other types of behavior (within which we can include BED), which he calls normal value constant repulsive. These are pathological constants, because they express the death of normativity. Resurrecting normativity, developing activation pathways of the "normal constant propulsive value" can be one of the central goals in the praxis of FNE.

The woman with BED is within a repulsive value constant, because she starts reacting to any changes in her environment with the same stereotyped and crystallized behavior. She loses the opportunity to be able to innovate. In this respect, her creativity is compromised because she can only deal with stressful situations if she uses food as an 'emotional cushion'.

To be free, in the sense of healing, according to Canguilhem, you have to take your treatment and your life history in an active and engaged form, feeling part and agent of your self transformation and healing process. In this space, the FNE conceived in the scope of an ethicalpolitical ${ }^{47}$ way of caring is a space of fundamental importance for the strategic and specific nature of its practice, in potential terms.

Finally, nothing more appropriate than the words of a great writer, a wise man who helps us summarize the challenge of our respondents in their quest for healing: "Human beings are not born once and for all on the day their mothers give birth to them ... Life always requires that they always give birth to themselves" 48 .

In order to allow this process of healing, not in the biomedical sense, but full-term, these people require assistance of health professionals that can really offer listening and a differentiated performance, developing more powerful lines of care, in which FNE, as we have seen, can occupy a key place in the necessary reinvention of themselves and their relationship with food.

\section{REFERE N CES}

1. Gadamer H-G. A extensão da questão da verdade à compreensão nas ciências do espírito. Verdade e método. Petrópolis: Vozes; 1997. p.273-556.

2. Amatuzzi M. Apontamentos acerca da pesquisa fenomenológica. Estud Psicol (Campinas). 1996; 13(1):5-10. http://dx.doi.org/10.1590/S0103166 X2010000200013

3. Forghieri YC. Psicologia fenomenológica: fundamentos, método e pesquisas. São Paulo: Pioneira; 1993.

4. Bosi MLM. A Face Oculta da Nutrição: ciência e ideologia. Rio de Janeiro: EDUFRJ; 1988.

5. Andrade A, Bosi MLM. Transtornos alimentares e sociedade de consumo: um mosaico simbólico que emerge frente às patologias Narcísicas da atualidade. Rev Cent Ciênc Saúde. 2002; 15(2):1-7.

6. Morin E. A cabeça bem-feita: repensar a reforma, reformar o pensamento. $9^{a}$ ed. Rio de Janeiro: Bertrand do Brasil; 2004.

7. Silva M. Sala de aula interativa. $6^{a}$ ed. São Paulo: Loyola; 2012.

8. Freire P. Pedagogia da autonomia: saberes necessários à prática educativa. São Paulo: Paz e Terra; 1996.

9. Prado SD, Bosi MLM, Carvalho MCVS, Gugelmen AS, Mattos RA, Camargo Junior KR, et al. Alimentação e nutrição como campo científico autô- 
nomo no Brasil: conceitos, domínios e projetos políticos. Rev Nutr. 2011; 24(6):927-38. http://dx.doi. org/10.1590/S1415-52732011000600013

10. Carvalho MCVS, Luz MT, Prado SD. Comer, alimentar e nutrir: categorias analíticas instrumentais no campo da pesquisa científica. Ciênc Saúde Coletiva. 2011; 16(1):155-63. http://dx.doi.org/10.15 90/S1413-81232011000100019

11. Teixeira Márcia J. Fome de vida: vivências e percepções de mulheres obesas portadoras do transtorno da compulsão alimentar periódica. [mestrado]. Rio de Janeiro: Universidade Federal do Rio de Janeiro; 2003.

12. Pinto MS, Bosi MLM. Muito mais do que pe(n)sam: percepções e experiências acerca da obesidade entre usuárias da rede pública de saúde de um município do Nordeste do Brasil. Physis. 2010, 20(2):443-57. http://dx.doi.org/10.1590/S0103-73 312010000200006

13. Nunes MA, Apolinário JC, Abuchaim ALG, Coutinho W. Transtornos alimentares e obesidade. Porto Alegre: Artmed; 1998.

14. Coutinho W. Consenso Latino Americano de Obesidade. Arq Bras Endocrinol.1999; 43(1):21-67.

15. Freitas S, Lopes CS, Coutinho W, Apolinário JC. Tradução e adaptação para o português da Escala de Compulsão Alimentar Periódica. Rev Bras Psiquiatria. 2001; 23(4):215-20.

16. American Psychiatric Association. DSM IV: Diagnostic and Statistical Manual of Mental Disorders. Washington (DC): APA; 1994.

17. Borges MBF. Estudo do transtorno da compulsão alimentar periódica e sua associação com depressão e alexitimia [mestrado]. São Paulo: Universidade Federal de São Paulo; 1998.

18. Costa RF, Machado SC, Cordas TA. Imagem corporal e comportamento sexual de mulheres obesas com e sem transtorno da compulsão ali-mentar periódica. Rev Psiquiatr Clín. 2010; 37(1):27-31. http://dx.doi.org/10.1590/S0101-6083201000 0100006

19. Bittencourt AS, Lucena-Santos P, Moraes JFD, Oliveira, MS. Anxiety and depression symptoms in women with and without binge eating disorder enrolled in weight loss programs. Trends Psychiat Psychother. 2012; 349(2):87-92. http://dx.doi.org/ 10.1590/S2237-60892012000200007

20. Bernardi F, Harb ABC, Levandovski RM, Hidalgo MPL. Transtornos alimentares e padrão circadiano alimentar: uma revisão. Rev Psiquiatr. 2009; 31(3):170-76. http://dx.doi.org/10.1590/S0101-81 082009000300006

21. Palavras MA, Kaio GH, Mari JJ, Claudino AM. Uma revisão dos estudos latino-americanos sobre o transtorno da compulsão alimentar periódica. Rev Bras Psiquiatr. 2011; 33(supl. 1):S95-S108 http:// dx.doi.org/10.1590/S1516-44462011000500007

22. Borges MBF, Jorge M. Evolução histórica do conceito de compulsão alimentar. Psiquiatr Prát Méd 2000; 33(4):113-18.

23. Amorim M, Kaio GH, Mari JJ, Claudino AM. Uma revisão dos estudos latino-americanos sobre o transtorno da compulsão alimentar periódica. Rev Bras Psiquiatr. 2011; 33(Suppl.):81-94. http://dx. doi.org/10.1590/S1516-44462011000500007

24. Limoeiro C. Ideologia de desenvolvimento. Brasil: JK-JQ. 2 ${ }^{a}$ ed. Rio de Janeiro: Paz e Terra; 1978.

25. Nunes $M O$, Bittencourt $L$. No rastro do que transtorna o corpo e desregra o comer: os sentidos do descontrole de si e das "compulsões alimentares". Interface. 2013; 17(44):145-57. http://dx.doi.org/ 10.1590/S1414-32832013000100012

26. Bruns AM, Holanda AF, Organizadores. Psicologia e pesquisa fenomenológica: reflexões e perspectivas. São Paulo: Omega; 2001.

27. Organização Mundial da Saúde. CID-10 Classificação estatística internacional de doenças e problemas relacionados à saúde. 10ª ed. São Paulo: Universidade de São Paulo; 1997.

28. American Psychiatric Association. DSM IV: Diagnostic and Statistical Manual of Mental Disorders. Washington (DC): APA; 1994.

29. Appolinário JC, Coutinho W, Povoa LC. O transtorno do comer compulsivo: revisão de literatura. J Bras Psiquiat. 1995; 44 (supl. 1):38-40.

30. Cukier R. Sobrevivência emocional: as dores da infância revividas no drama adulto. São Paulo: Ágora; 1998.

31. Barbosa MI. O Vínculo na atenção básica em saúde [doutorado], Fortaleza: Universidade Federal do Ceará; 2015.

32. Fairburn CG, Wilson GT. Binge eating: Nature, assessment and treatment. New York: The Guilford Press; 1993.

33. Greeson J. Não é o que você está comendo, é o que você está remoendo. Rio de Janeiro: Record; 1991.

34. Leloup JY. O corpo e seus símbolos. uma antropologia essencial. 20ª ed. Petropolis: Vozes; 2012.

35. Medeiros G. O gordo absolvido. São Paulo: ARX; 2002.

36. Bosi MLM, Teixeira MJ. Experiências na interface corpo obeso-mundo: focalizando o transtorno da compulsão alimentar periódica. In: Amorim R, Catrib AMF, Jorge MSB. Olhares da saúde coletiva sobre o corpo. Fortaleza: UECE; 2011. 
37. Stenzel L M. Obesidade: o peso da exclusão. Porto Alegre: EDIPUCRS; 2002.

38. Andrade A. Para além dos sintomas: a trilogia do desamparo no vivido de mulheres com transtornos do comportamento alimentar [mestrado]. Fortaleza: Universidade Federal do Ceará; 2000.

39. Lipowetsky G. A Terceira mulher: permanência e revolução do feminino. São Paulo: Cia das Letras, 2000.

40. Fandiño J, Benchimol AK. Caoutinho WF, Appolinário JC. Cirurgia bariátrica: aspectos clínico-cirúrgicos e psiquiátricos. Rev psiquiatr. Rio Grande Sul. 2004; 26(1):47-51. http://dx.doi.org/10.1590/S0101-810 82004000100007.

41. Hycner R, Jacob L. Relação e cura em Gestalt-terapia. São Paulo: Summus; 1997.

42. Carvalho-Ferreira JP, Cipullo MAT, Coranti DA, Masquito DCL, Andrade-Silva SG, Pesane LPP et al. Terapia interdisciplinar de mudança do estilo de vida melhora sintomas de compulsão alimentar e insatisfação com a imagem corporal em adultos obesos brasileiros. Trends Psychiatry Psychother.
2012; 34(4):223-233. http://dx.doi.org/10.1590/ S2237-60892012000400008

43. Albers S. Using mindful eating to treat food restriction: A case study. Eat Disord. 2011; 19(1):97-107.

44. Denny KN, Loth K, Eisenberg ME, Neumark-Sztainer $D$. Intuitive eating in young adults. Who is doing it, and how is it related to disordered eating behaviours? Appetite. 2013; 60(1):13-9.

45. Fellipe FM. O peso social da obesidade [doutorado]. Porto Alegre: Pontifícia Universidade Católica do Rio Grande do Sul; 2001.

46. Canguilhem G. O normal e o patológico. Rio de Janeiro: Forense Universitária; 2000.

47. Carvalho LB, Freire JC, Bosi MLM. Alteridade radical: implicações para o cuidado em saúde. Physis. 2009; 19(3):849-65.

48. García Márquez G. O amor nos tempos do cólera. Rio de Janeiro: Record; 2009.

Received: May 1, 2016

Final version: June 18, 2016

Approved: August 9, 2016 
